\title{
The Impact of Alternative SoIL Tillage ON SOIL RESISTANCE AND $\mathrm{CO}_{2}$ EMISSIONS
}

\author{
STAJNKO, D.; VINDIS, P. \& BERK, P.
}

Abstract: The alternative soil tillage (CP) and mouldboard ploughing (MP) was applied for five years on a heavy soil under Slovenian agro-ecological conditions. The measurements of horizontal resistance with horizontal penetrometer were performed at 15, 25 and $35 \mathrm{~cm}$ layer depth on $375 \mathrm{~m}$ long experimental parcel. In the $15 \mathrm{~cm}$ layer significant lower resistance was detected in MP15 $\left(40.98 \mathrm{Ncm}^{-2}\right)$ than in CP15 (45.10 $\left.\mathrm{Ncm}^{-2}\right)$, while in $25 \mathrm{~cm}$ layer higher resistance was measured in CP25 $\left(122.47 \mathrm{Ncm}^{-2}\right)$ than in MP25 $\left(91.66 \mathrm{Ncm}^{-2}\right)$. The measurement of $\mathrm{CO}_{2}$ emissions from the soil were carried out by the LC pro+ device during the whole year in hourly interval. Significant lower emissions $(31.934 \mathrm{Mg} / \mathrm{ha}$ day in January and 52.464 $\mathrm{Mg} / \mathrm{ha}$ day in June) were measured in the CP in comparison with the MP (112.527 $\mathrm{Mg} / \mathrm{ha}$ day in January and $144.460 \mathrm{Mg} / \mathrm{ha}$ day in June).

Key words: soil resistance, soil tillage, chisel, mouldboard plough, $\mathrm{CO}_{2}$ emissions
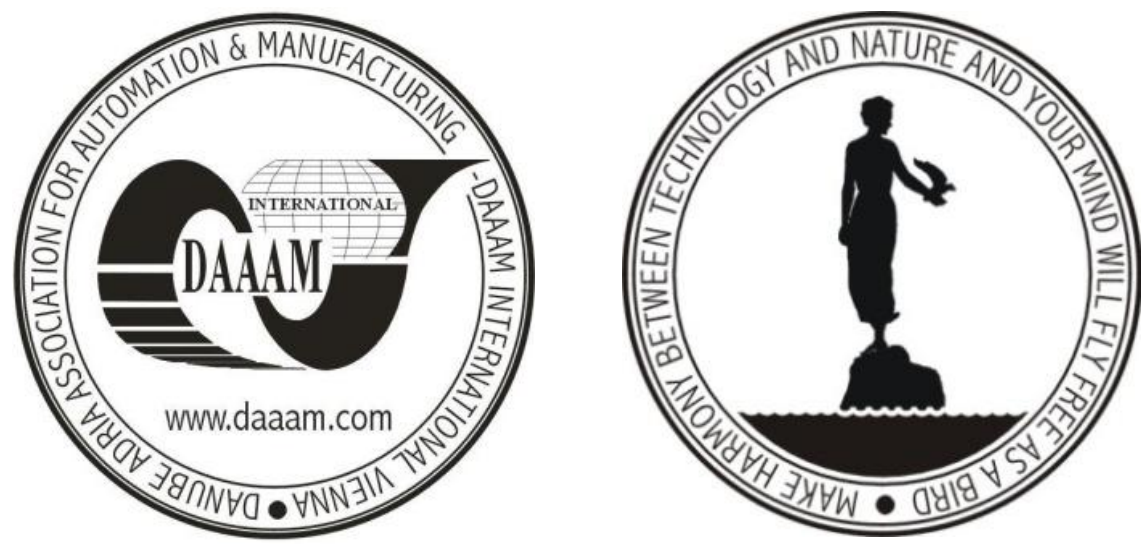

Authors' data: Assoc. Prof. Stajnko, D[enis]; Assist. Prof. Vindis, P[eter]; Bs. Electro. Eng. Berk, P[eter], University of Maribor, Faculty of Agriculture and Life Sciences, Pivola 10, SI-2311, Hoče, Slovenia, denis.stajnko@uni-mb.si, peter.vindis@uni-mb.si, peter.berk@uni-mb.si

This Publication has to be referred as: Stajnko, D[enis]; Vindis, P[eter] \& Berk, P[eter] (2012). The Impact of Alternative Soil Tillage on Soil Resistance and $\mathrm{CO}_{2}$ Emissions, Chapter 30 in DAAAM International Scientific Book 2012, pp. 357-368, B. Katalinic (Ed.), Published by DAAAM International, ISBN 978-3-901509-86-5, ISSN 1726-9687, Vienna, Austria

DOI: 10.2507/daaam.scibook.2012.30 
Stajnko, D.; Vindis, P. \& Berk, P.: The Impact of Alternative Soil Tillage on Soil ...

\section{Introduction}

Soil organic matter (SOM) is crucial for maintaining soil fertility because it stabilizes soil structures against erosive forces and increases water capacity and nutrient availability. Increasing SOM on agricultural land could provide a potential sink for atmospheric carbon whenever alternative soil tillage is applied (Ellert \& Janzen, 1999; Reicosky et al., 1999). However, a long-term conventional tillage with mouldboard plough causes severe SOM reduction in agricultural soils (Six et al., 2000) and is responsible for reducing soil organic carbon levels by up to $70 \%$ (Lal \& Bruce, 1999).

According to the world's scientists and politicians, global warming is mostly caused by greenhouse gases in the atmosphere descend through human activities, which also involves agriculture. In the Slovenian agriculture for processing of one hectare of land on average $184.83 \mathrm{l} \mathrm{ha}^{-1}$ fuel is spent, which released $508.282 \mathrm{~kg} \mathrm{CO}_{2}$ $\mathrm{ha}^{-1}$ when burned. The largest proportion $38 \%\left(70.231 \mathrm{ha}^{-1}\right)$ is used for the basic soil preparation. Stajnko et al., 2009a proved that the direct drilling can save between $78.43 \%$ and $81.42 \%$ of fuel as well as alternative tillage can decrease the diesel consumption between $33.291 \mathrm{ha}^{-1}(48.68 \%)$ and $36.031 \mathrm{ha}^{-1}(52.00 \%)$ depending on soil type and moisture. In several field experiments the $\mathrm{CO}_{2}$ emissions was decreased on average for $161.71 \mathrm{~kg} \mathrm{CO}_{2} \mathrm{ha}^{-1}$ in direct drilling and for $103.13 \mathrm{~kg} \mathrm{CO}_{2} \mathrm{ha}^{-1}$ in reduced tillage.

Moreover, the conventional soil tillage with mouldboard plough also emits into the atmosphere important quantities of $\mathrm{CO}_{2}$ gases as the result of microbial decomposition of the soil humus thus modified methods of tillage can reduce direct emissions of $\mathrm{CO}_{2}$ significantly. Furthermore undistorted soil can act as a sink for atmospheric $\mathrm{CO}_{2}$ being produced in industry and traffic. Many authors have confirmed the impact of long-term absence of ploughing on the increase of SOM, which however depend also on soil type. Direct sowing and mulch tillage as two most important alternative tillage methods increases SOM content and organic carbon in the surface layer of soil and microbial biomass. Gregorich et al., 2005 found that direct sowing accumulate $42-50 \%$ more organic carbon in the surface layer of soil than conventional tillage. Furthermore, the minimum tillage and direct sowing can accumulate more organic carbon in the surface layer of soil when compared with conventional treatment. Stockfisch et al., 1999, after 20 years of mulch tillage measured increase in SOM and total microbial biomass. However, the mere one-year change in the conventional treatment, can be completely offset several years accumulation of organic matter.

Cookson et al., 2008, also found more total organic carbon in topsoil in direct sowing and conservation tillage compared with ploughing. However, on the average there was no difference in treatment between all depths. Wang et al., 2008, additionally reported that direct sowing without removal of crop residues can increase not only organic matter in soil by $21.7 \%$, but also total nitrogen by $51 \%$ and available phosphorus by $97.3 \%$ in the $0-10 \mathrm{~cm}$ layer in comparison with conventional treatment of soil by the removal of crop residues. Also Etana et al., 1999, measured in the shallow cultivated soil the increase in 
concentration of organic carbon in the surface layer of soil, while in the deeper layers it remains unchanged. Álvaro-Fuentes et al., 2009 found that reducing the intensity of tillage and more diverse crop rotation can increase the organic carbon in soil.

On the other hand convention tillage increases also the risk of soil compaction as the number of farm operations and the use of heavier machinery is rising in the modern agriculture. According to Gill \& Van den Berg (1968) soil compaction is the process in which the soil particles are rearranged to decrease empty space and bring them into closer contact with one another so increasing the bulk density. The major contributor to forming soil compaction is various loads applied to the surface of unsaturated soils.

Consequently, excessive soil compaction has negative effects on soil structure, reduces crop production, increases runoff and erosion, accelerates potential pollution of surface water by organic waste and applied agrochemicals, and causes inefficient use of water and nutrients due to slow drainage (Johnson \& Bailey, 2002).

Quantitative evaluation of soil compaction is necessary to determine its severity and to identify suitable mechanical, chemical, or biological methods of intervention for ameliorating or controlling soil compaction. Two different methods are commonly used for measuring soil penetration resistance. In the first method, soil samples are taken over the field at a certain depth of soil with the help of an openended pipe and then the samples are analyzed in the laboratory to determine dry bulk density, dry specific volume, void ratio, and porosity (Hao et al, 2008). In the second method, a specifically sized conical tip is immersed into the ground vertically or horizontally to measure soil strength at a standard speed of $30 \mathrm{~mm} / \mathrm{s}$ (Jones \& Kunze, 2004). Soil strength has been widely used to estimate the degree of soil compaction. By nature, soil strength sensors are of soil failure-type. As this type of sensor is moved through the soil, it registers resistance forces arising from cutting, breakage and displacement of soil.

Contrary to the vertical penetrometer, which enables only point measurements of the soil strength, horizontal penetrometer can make instantaneous measurements during driving. Result of the measurement is a signal obtained at a certain distance, which is selected for measurement. The values obtained at a distance which is defined and a constant speed of movement of the tractor allows the evaluation of higher quality data, because one can reduce the impact of soil inhomogeneity due to large amounts of measured values (Jejčič \& Poje, 1995).

During 2011 two studies were performed (i) to determine the effect of alternative soil tillage (chisel plough) on the horizontal soil resistance and (ii) to measure the $\mathrm{CO}_{2}$ emission from the soil which is an important indicator of soil fertility.

In the following chapters we are going to present the result of five-year alternative soil tillage with chisel plough and mouldboard ploughing on horizontal resistance of the soil and the $\mathrm{CO}_{2}$ emissions from the soil on a silty clay loam soil (Gleyic Podzoluvisol) under Slovenian agro-ecological conditions. 
Stajnko, D.; Vindis, P. \& Berk, P.: The Impact of Alternative Soil Tillage on Soil ...

\section{Measuring of soil compaction}

For our investigation in 2011 a field called 'Center' (Lat. E 1540'36" Long N $\left.46^{\circ} 35^{\prime} 58^{\prime \prime}\right)$ was selected. Since 2005 the half of the parcel was conventionally tilled with a moulboard plough (Lemken, Albatros 5, Fig. 1), while on the other half a chisel Vederstadt Top Down 600, (Fig. 2) was applied in the alternative tillage. The rotation corn - winter raps - winter wheat was the same on both sub parcels.

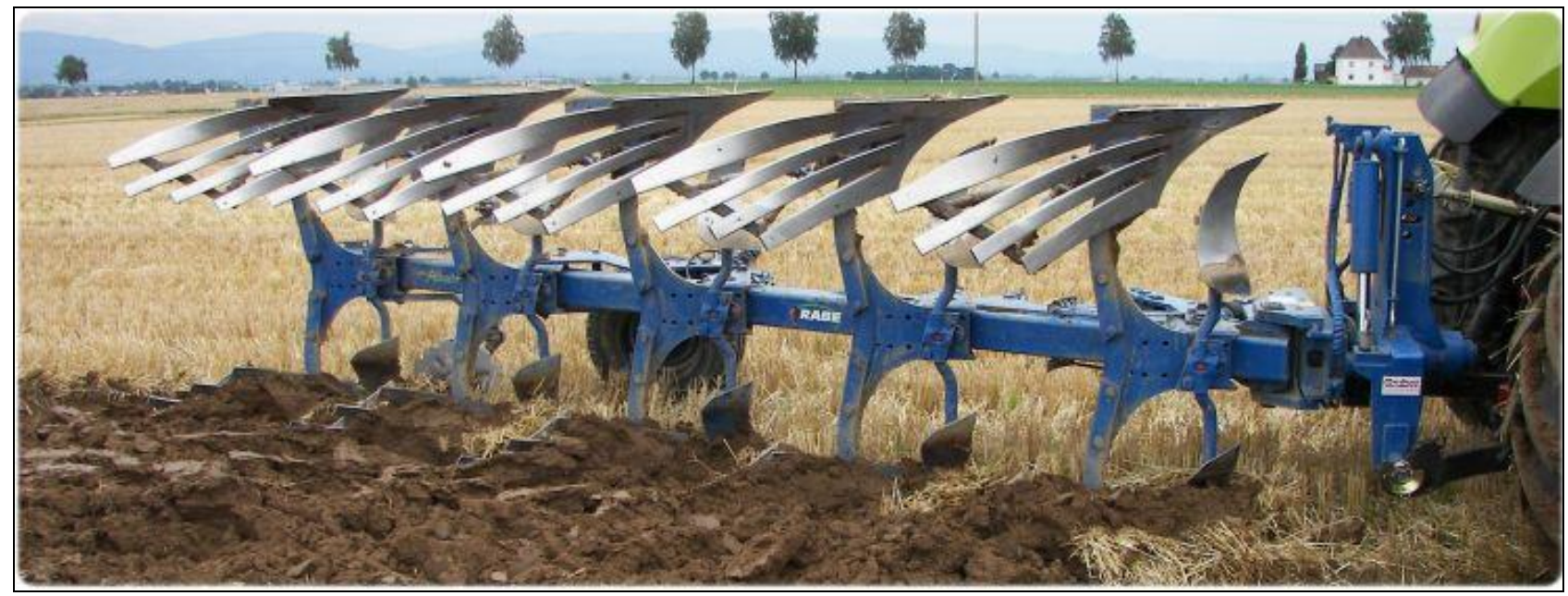

Fig. 1. Lemken Albatros 5

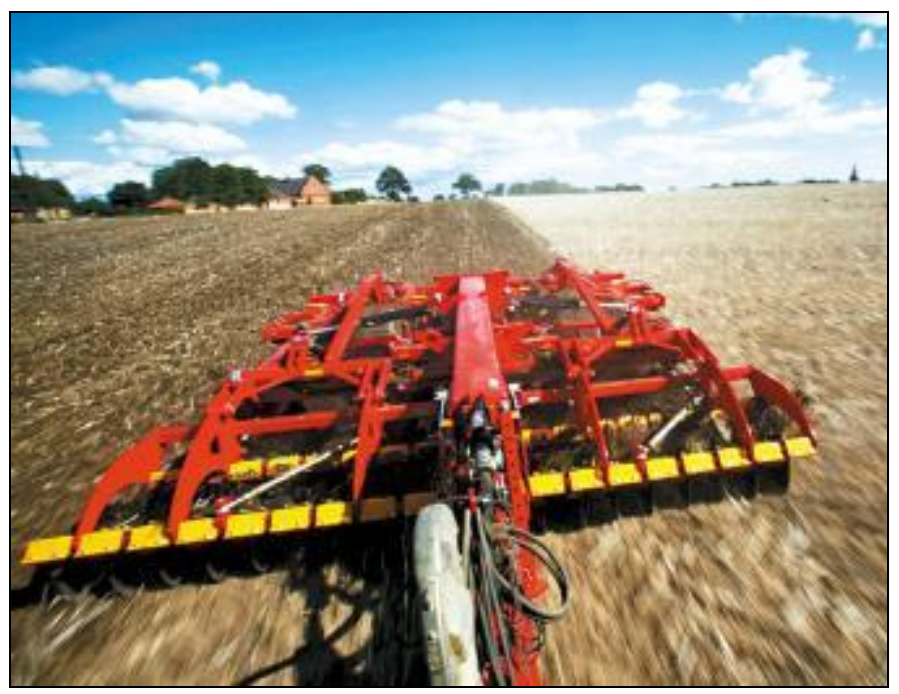

Fig. 2. Vederstadt Top Down 600

\section{Horizontal penetrometer}

For measuring soil horizontal resistance a horizontal penetrometer was used (Fig. 3), which is represented in details on Fig. 4. The conical tip of the horizontal penetrometer was made of steel. The load cell bed was formed into the steel tine. The load cell was placed in this section and the top was covered. This prevents possible damage to the load cells under the soil. The data cables of the load cells were transported to the data collection unit, which was placed on the nearby driving vehicle, by being passed through the metal tubes placed behind the penetrometer's 
tip. Afterwards, a conical-shaped tip of $30^{\circ}$ was placed into the hole, and fixed to the load cell. The surface of the designed conical-shaped tip is $18.08 \mathrm{~cm}^{2}$. Insulation seals were used in order to prevent probable leakage of water or soil particles into the holes on the body. An adjustable wheel system was placed behind the penetrometer to ensure a well-maintained depth adjustment and proper running of the machine. By changing the inclination of knife holder of penetrometer and by releasing the hydraulic tractor drawbar we achieve that the penetrometer is buried below the topsoil at the proper depth and guided by a horizontal plane (Jejčič \& Poje 1996).

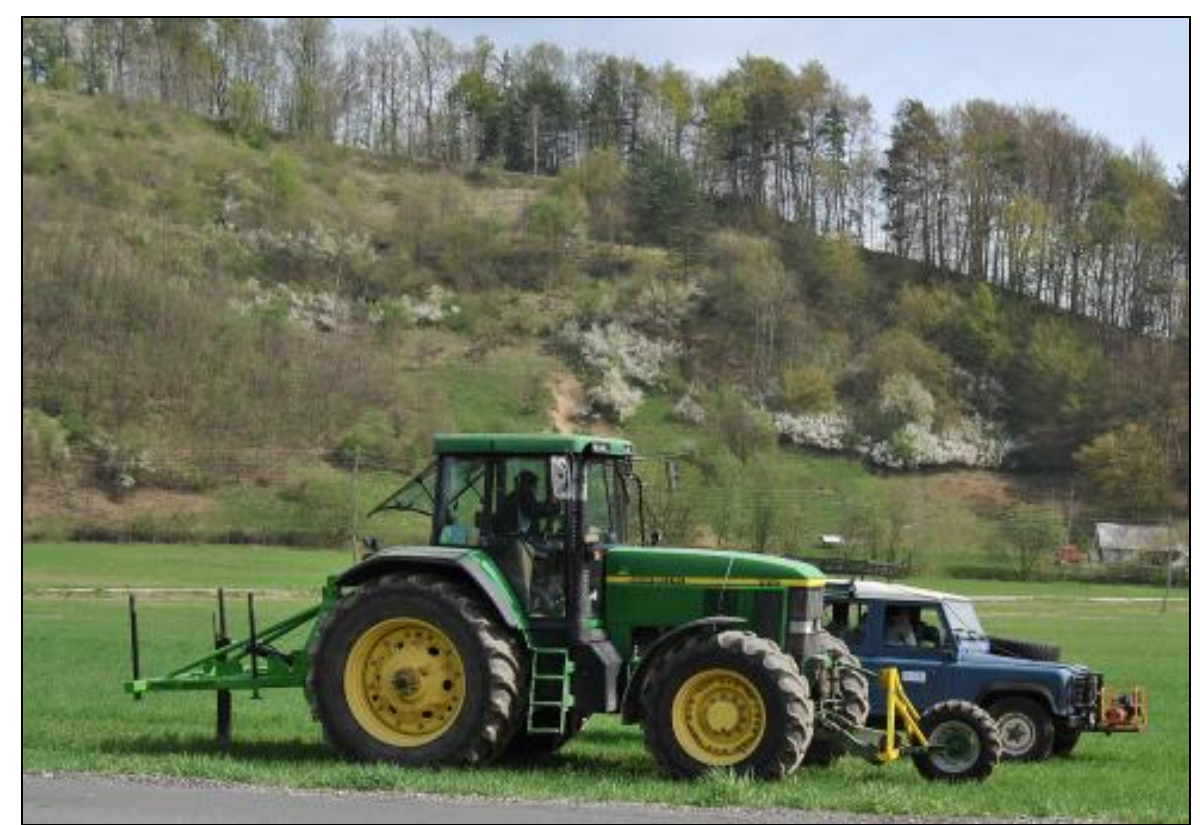

Fig. 3. Horizontal penetrometer during measuring on the field in May 2011

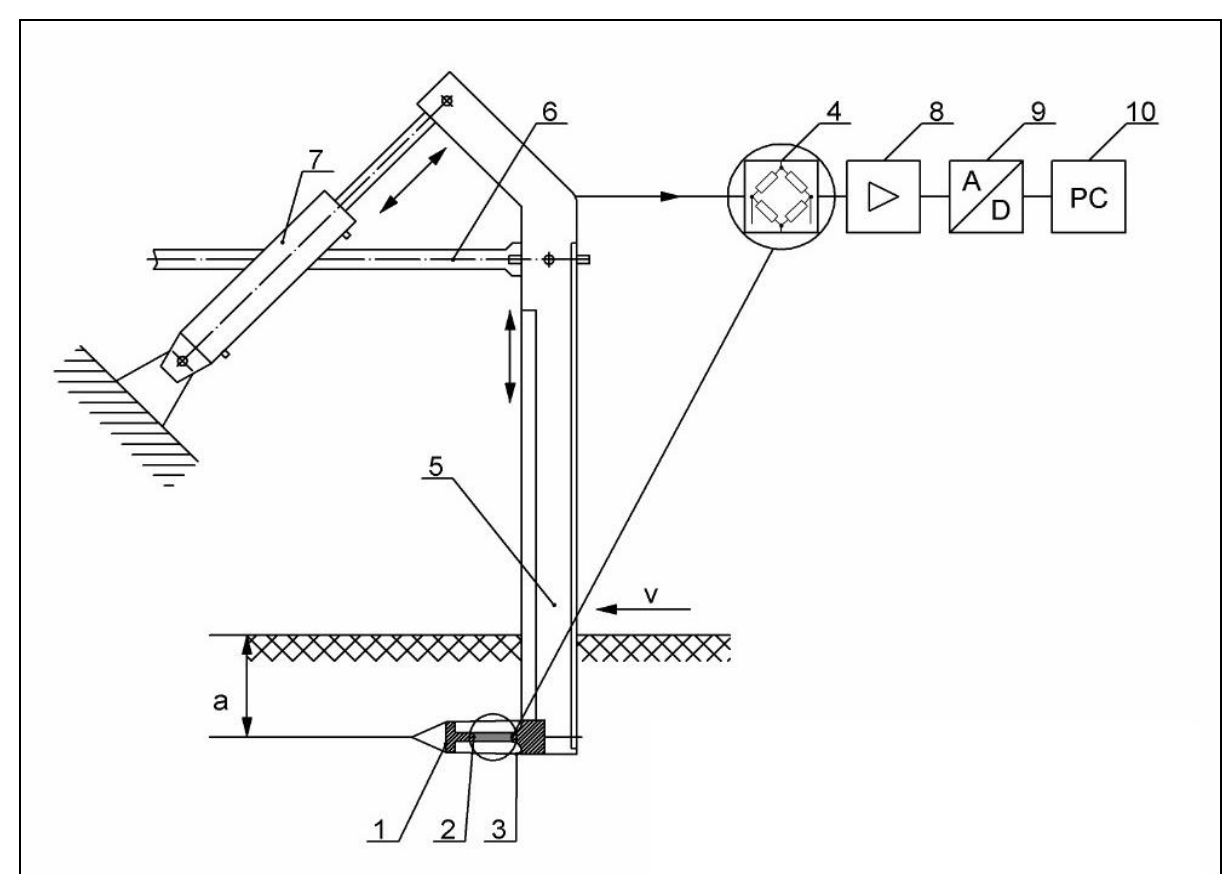

Fig. 4. Horizontal penetrometer: 1 - conical tip, 2 - sensor of compressive force, 3 protective armour, 4 - strain gauges, 5 - medium, 6 - tractor drawbar, 7 - hydraulic cylinder for adjusting tilt, 8 - magnifying glass, 9 - A/D converter, 10 - personal computer (Jejčič \& Poje 1996) 
Stajnko, D.; Vindis, P. \& Berk, P.: The Impact of Alternative Soil Tillage on Soil ...

\subsection{Average horizontal soil resistance}

Fig. 5 shows measurements of the horizontal resistance on the field parcel in May 2011, which was ploughed in the last years. Additional statistics may be seen in Tab. 1, which shows the highest average horizontal soil resistance in the depth of 35 $\mathrm{cm}\left(124.77 \mathrm{Ncm}^{-2}\right)$ and the lowest in the depth of $15 \mathrm{~cm}\left(40.98 \mathrm{Ncm}^{-2}\right)$. In the deepest layer the maximum soil resistance $\left(184.36 \mathrm{~N} / \mathrm{cm}^{2}\right)$ was also detected, but it did not differ significantly from the maximum point in the $25 \mathrm{~cm}$ layer. On the other hand, in the $15 \mathrm{~cm}$ layer the values remains minimal during all the measurements.

\begin{tabular}{|c|c|c|c|c|}
\hline $\begin{array}{c}\text { Depth } \\
(\mathrm{cm})\end{array}$ & $\begin{array}{c}\text { Average } \\
\left(\mathrm{Ncm}^{-2}\right)\end{array}$ & $\begin{array}{c}\text { Standard } \\
\text { deviation }^{\left(\mathrm{Ncm}^{-2}\right)}\end{array}$ & $\begin{array}{c}\text { Maximum } \\
\left(\mathrm{Ncm}^{-2}\right)\end{array}$ & $\begin{array}{c}\text { Minimum } \\
\left(\mathrm{Ncm}^{-2}\right)\end{array}$ \\
\hline 15 & $40.98^{\mathrm{a}}{ }^{\mathrm{a}}$ & 10.76 & 77.00 & 16.26 \\
\hline 25 & $91.67^{\mathrm{b}}$ & 29.10 & 183.28 & 31.45 \\
\hline 35 & $124.77^{\mathrm{b}}$ & 15.66 & 184.36 & 84.59 \\
\hline
\end{tabular}

${ }^{\mathrm{a}, \mathrm{b}}$ statistically significant difference at $\mathrm{p}<0.05$ (Duncan test)

Tab. 1. Average horizontal soil resistance on the parcel 'plough' in May 2011

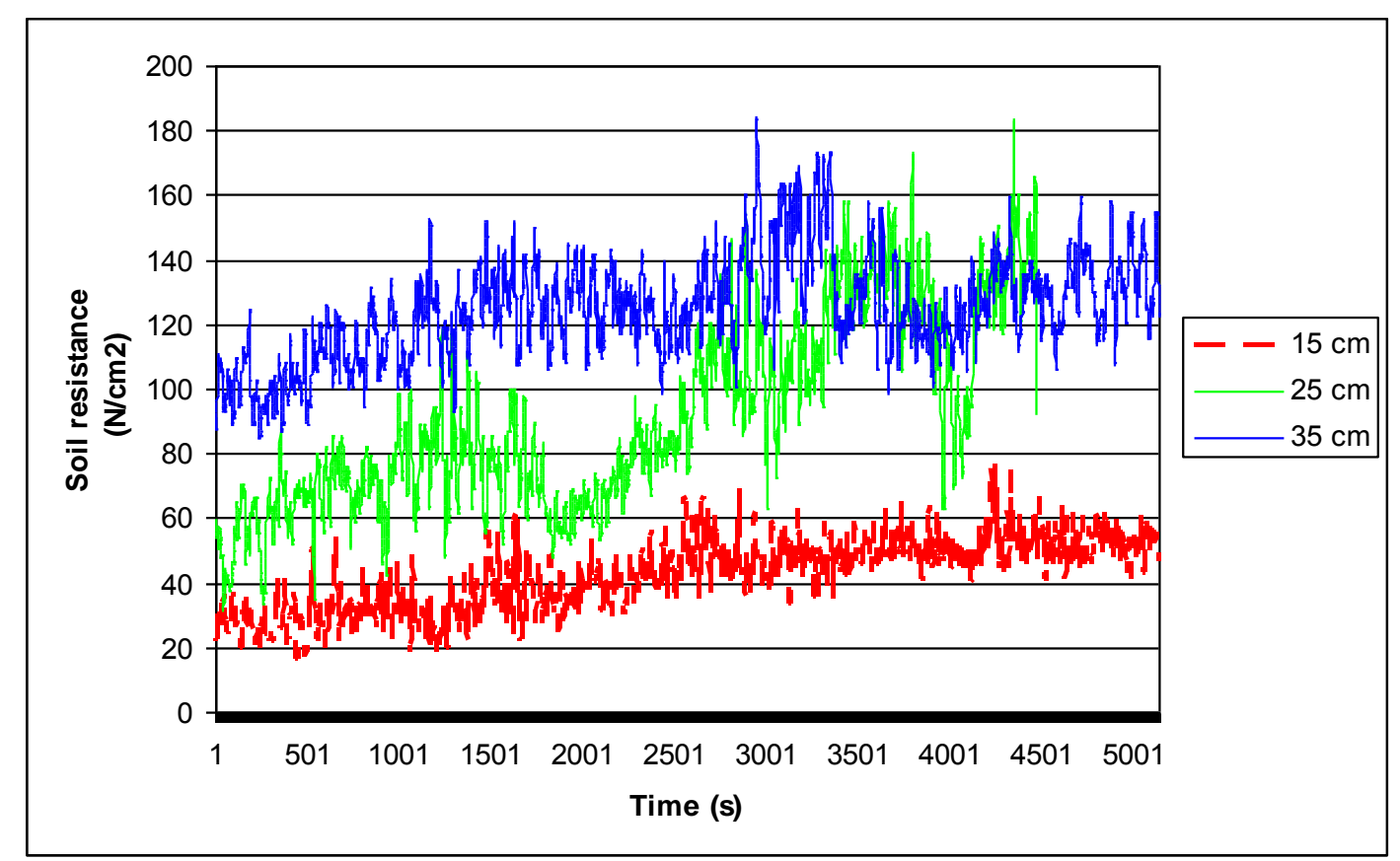

Fig. 5. Horizontal soil resistance in three soil layers on the subparcel 'plough' in May 2011

Fig. 6 represents measurements (May 2001) of the horizontal resistance on the part of field, which was chiselled with Vederstadt Top Down 600 in the last five years. In the Tab. 2 additional statistics is shown. Again the highest average horizontal soil resistance was measured in the deepest depth of $35 \mathrm{~cm}\left(120.05 \mathrm{Ncm}^{-2}\right)$ and the lowest in the depth of $15 \mathrm{~cm}\left(62.57 \mathrm{Ncm}^{-2}\right)$. In the deepest layer we did also detect the maximum soil resistance $\left(161.59 \mathrm{Ncm}^{-2}\right)$, but it did not differ significantly 
from the maximum value in the $25 \mathrm{~cm}$ layer. The minimum values remained during all the measurements in the $15 \mathrm{~cm}$ layer.

\begin{tabular}{|c|c|c|c|c|}
\hline $\begin{array}{ll} & \text { Dept } \\
\text { h } & \\
& \text { (cm) }\end{array}$ & $\begin{array}{l}\text { Average } \\
\left(\mathrm{Ncm}^{-2}\right)\end{array}$ & $\begin{array}{c}\text { Standard } \\
\text { deviation } \\
\left(\mathrm{Ncm}^{-2}\right)\end{array}$ & $\begin{array}{l}\text { Maximum } \\
\left(\mathrm{Ncm}^{-2}\right)\end{array}$ & $\begin{array}{l}\text { Minimum } \\
\left(\mathrm{Ncm}^{-2}\right)\end{array}$ \\
\hline 15 & $62.57^{\mathrm{a}}$ & 11.01 & 98.69 & 31.45 \\
\hline 25 & 91.67 & 29.10 & 135.56 & 33.62 \\
\hline 35 & $120.05^{b}$ & 15.97 & 161.59 & 60.73 \\
\hline
\end{tabular}

$\overline{\mathrm{a}, \mathrm{b}}$ statistically significant difference at $\mathrm{p}<0.05$

Tab. 2. Average horizontal soil resistance at chisel in May 2011

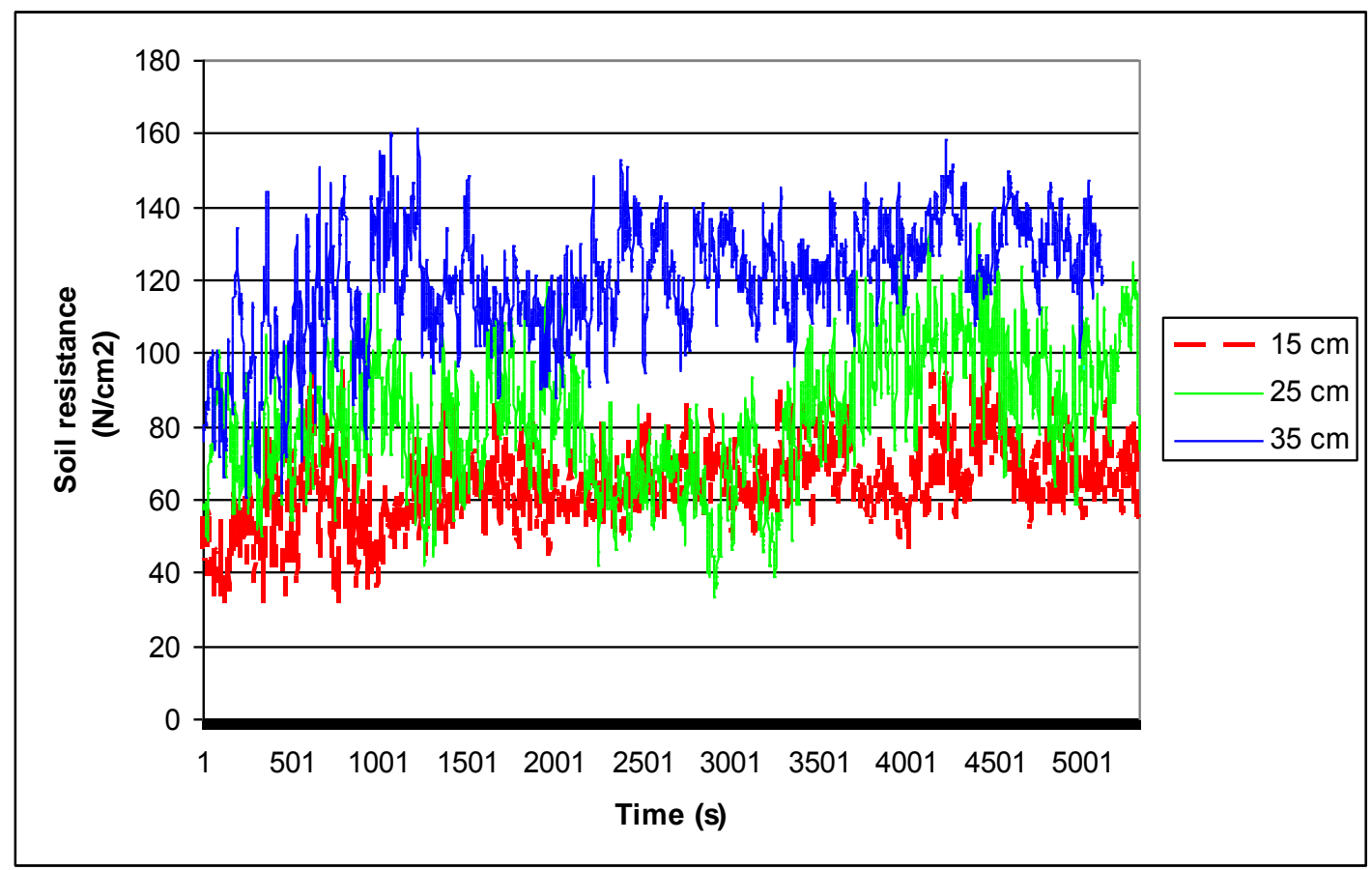

Fig. 6. Horizontal soil resistance in three soil layers on the sub parcel 'chisel' in May 2011

\section{4. $\mathrm{CO}_{2}$ monitoring}

The $\mathrm{CO}_{2}$ soil/air gas exchange monitoring was measured by using the infrared device (LC PRO, Fig.7a) and the soil hood (Fig.7b). Soil hood represents a chamber with incorporated enclosed volume used for the measurement of gas exchange. The LC uses the principal of Non Dispersive Infrared (NDIR) for the $\mathrm{CO}_{2}$ measurement in the range of $0-2000 \mathrm{ppm}$. This relies on the fact that $\mathrm{CO}_{2}$ absorbs energy in the infrared region in a proportion related to the concentration of the gas.

The dynamics of $\mathrm{CO}_{2}$ exchange from the soil in 2011 is represented in Fig. 8, which shows very small $\mathrm{CO}_{2}$ emissions in January and February, however a rapid increase followed in March, which is closely related to the temperature. Then on the plough and chisel plots values remained even from the end of March till late May and 
Stajnko, D.; Vindis, P. \& Berk, P.: The Impact of Alternative Soil Tillage on Soil ...

late June (control), respectively. The maximum 6.8 and $6.5 \mu \mathrm{mol} / \mathrm{m}^{2} \mathrm{~s}$ were measured on control plots.

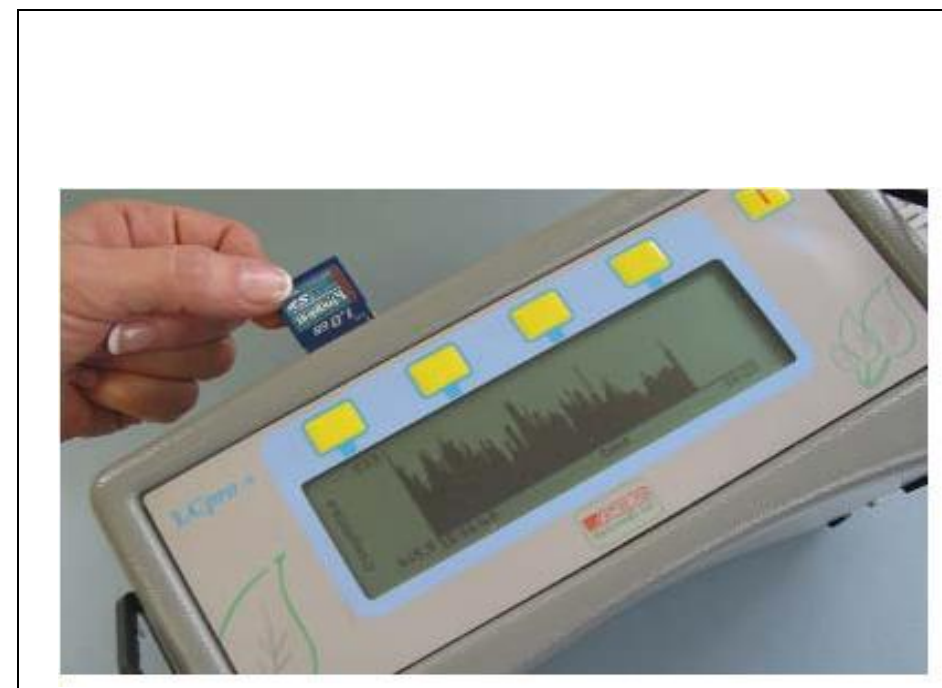

a)

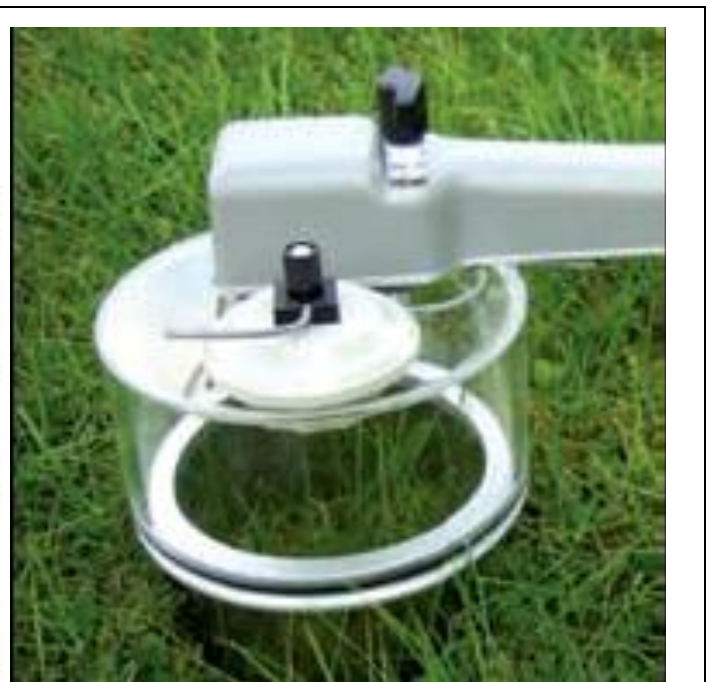

b)

Fig. 7. LC pro + device for measuring $\mathrm{CO}_{2}$ gas exchange (left), soil hood for collecting the gases from the soil (right)

\subsection{Development of $\mathrm{CO}_{2}$ gas exchange on different soil tillage}

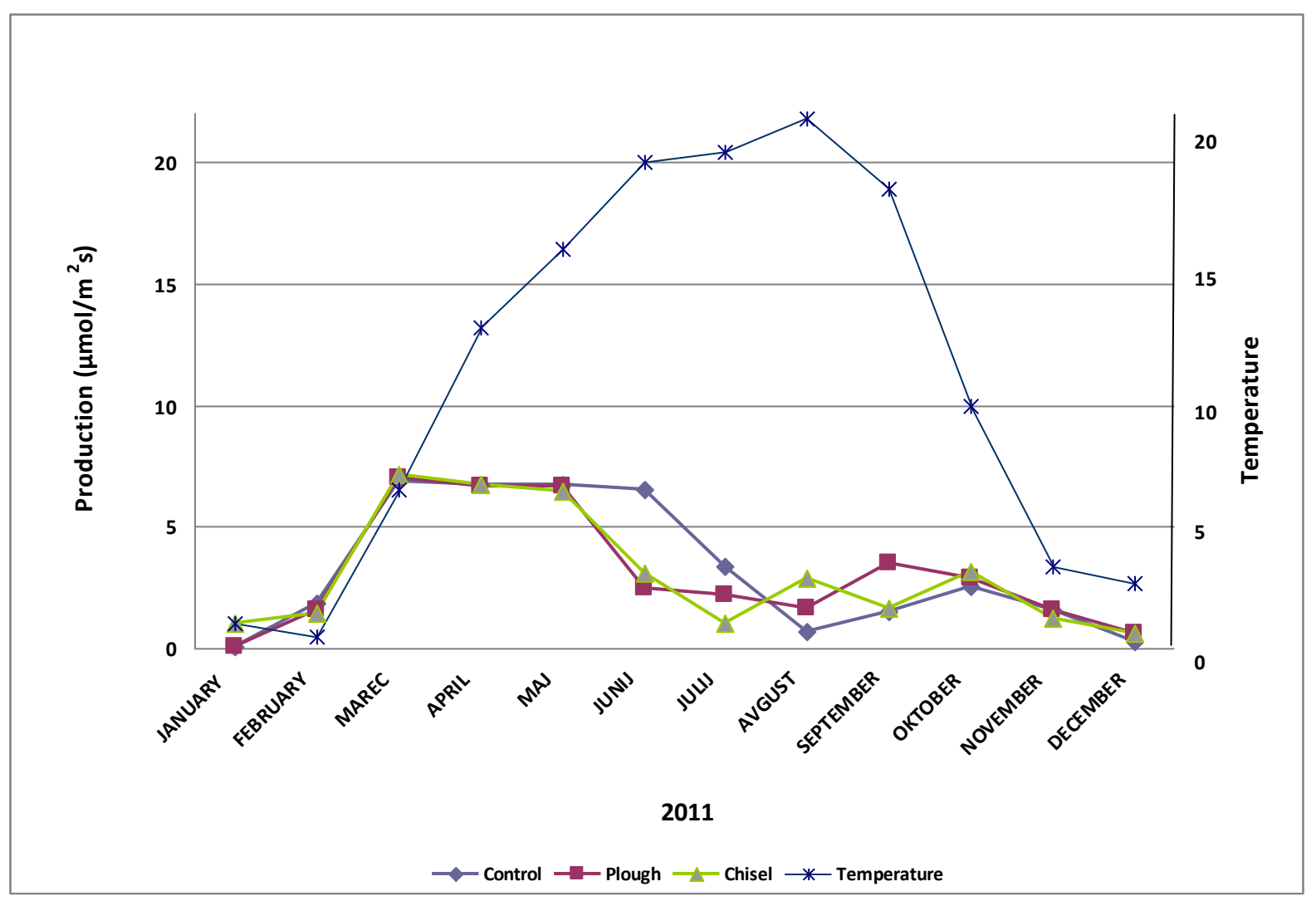

Fig. 8. The influence of different soil tillage on the $\mathrm{CO}_{2}$ gas exchange during 2011 on the silty clay loam soil 
In June and July all values showed again tendency of falling, whereby on the control parcel the same pattern was detected one month later than on chisel and plough parcels. In September and October the $\mathrm{CO}_{2}$ exchange raised for the second time because the soil was prepared for sowing of winter raps. So, it reached the maximum of $3.54 \mu \mathrm{mol} / \mathrm{m}^{2} \mathrm{~s}$ on the plough parcel and $1.54 \mu \mathrm{mol} / \mathrm{m}^{2} \mathrm{~s}$ on chisel parcel, respectively, but it did not exceeded the maximum spring values. In the last colder months of the year all values were falling little by little and reached their minimum in December.

Daily dynamics of $\mathrm{CO}_{2}$ exchange on January $20^{\text {th }} 2011$ (Fig. 9) shows on the average $2.96 \mu \mathrm{mol} / \mathrm{m}^{2} \mathrm{~s}\left(112.527 \mathrm{Mg} /\right.$ ha day) $\mathrm{CO}_{2}$ production on the parcel 'plough' and $2.12 \mu \mathrm{mol} / \mathrm{m}^{2} \mathrm{~s}(80.593 \mathrm{Mg} / \mathrm{ha}$ day $)$ on the parcel 'chisel' during the 24 hours observation with average soil temperature $3.7^{\circ} \mathrm{C}$. According to t-test $(\mathrm{p}<0.05)$ a significant lower emissions was measured by the alternative soil tillage in comparison to conventional tillage, which resulted in $31.934 \mathrm{Mg} / \mathrm{ha}$ day smaller emissions.

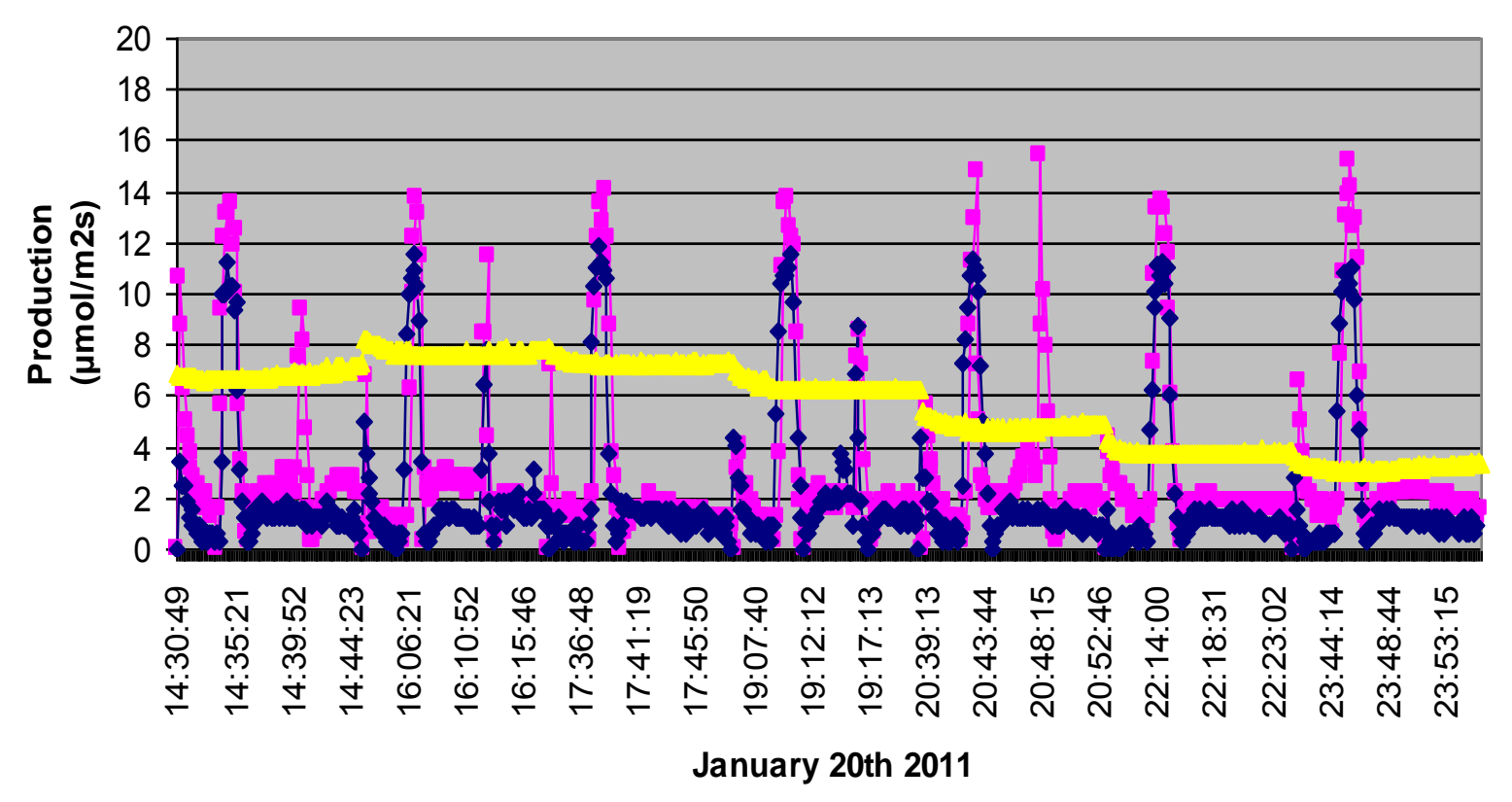

$\rightarrow-$ EMISSIONS PLOUGH $\rightarrow$ EMISSIONS CHISEL $\multimap$ TEMPERATURE

Fig. 9. 24-hours $\mathrm{CO}_{2}$ soil emissions on the warm winter day

In the summer the same pattern was measured again on June $6^{\text {th }} 2011$. On the average $3.80 \mu \mathrm{mol} / \mathrm{m}^{2} \mathrm{~s}\left(144.460 \mathrm{Mg} / \mathrm{ha}\right.$ day) $\mathrm{CO}_{2}$ soil emissions was measured on the parcel 'plough' during 24-hours measurements (Fig.10). On the warm summer day with the average soil temperature of $24.87^{\circ} \mathrm{C}$ this value is significantly higher in comparison with the 'chisel' parcel $\left(2.42 \mu \mathrm{mol} / \mathrm{m}^{2} \mathrm{~s}\right)$. From this reason a 52.464 $\mathrm{Mg} / \mathrm{ha}$ day $\mathrm{CO}_{2}$ less emissions was caused by the alterative tillage. 


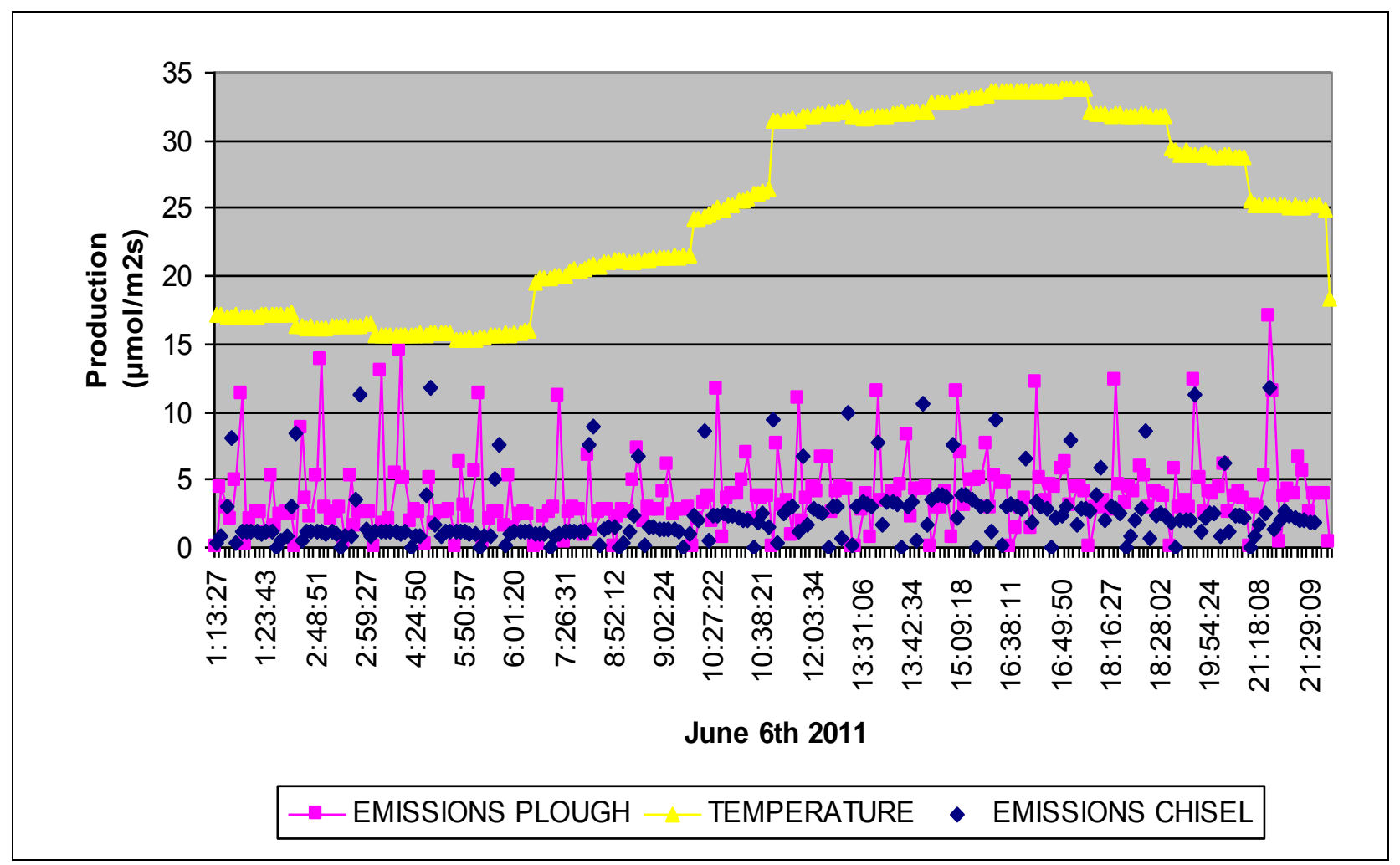

Fig. 10. 24-hours $\mathrm{CO}_{2}$ soil emissions on the warm summer day

\section{Conclusions}

Alternative soil tillage with chisel plough in comparison with mouldboard ploughing was proved in some previous experiments (Stajnko et al., 2009b) to reduce significantly the fuel consumption on the heavy silty clay loam soil (Gleyic Podzoluvisol). Subsequently the direct seeding system can decrease the $\mathrm{CO}_{2}$ emission up to $44.30 \mathrm{~kg} \mathrm{ha}^{-1}$ and the alternative tillage system up to $107.05 \mathrm{~kg} \mathrm{ha}^{-1}$, respectively.

The result of penetrometer measurements in May 2011 showed that using of alternative tillage (chisel Vederstadt Top Down 600) for five years increased the average soil resistance for $21.09 \mathrm{~N} / \mathrm{cm}^{2}$ in the top $15 \mathrm{~cm}$ soil layer in comparison with mouldboard plough. Contrary, in $25 \mathrm{~cm}$ and $35 \mathrm{~cm}$ layer no significant difference in the average horizontal resistance was determined between 'chisel' and 'plough' parcels.

In addition, the alternative tillage of the heavy silty soil with chisel showed also significant lower $\mathrm{CO}_{2}$ emissions in comparison with conventional tillage with mouldboard plough. For this reason a daily dynamics of $\mathrm{CO}_{2}$ exchange on January $20^{\text {th }} 2011$ was on average $2.96 \mu \mathrm{mol} / \mathrm{m}^{2} \mathrm{~s}$ on the parcel 'plough' and $2.12 \mu \mathrm{mol} / \mathrm{m}^{2} \mathrm{~s}$ on the parcel 'chisel' during the 24 hours observation. This means that an important reduction of $\mathrm{CO}_{2}$ fluxes from the soil can be achieved even during the winter periods with relatively small precipitations and mild temperatures, which usually increase speed the $\mathrm{CO}_{2}$ emissions. 


\section{Acknowledgements}

This research is an integral part of the CRP project No. V4-1062, entitled 'Exploring the effects of alternative soil tillage on soil fertility, humus increase as well the decrease of $\mathrm{CO}_{2}$ releases into the atmosphere' funded by ARRS and The Ministry of Agriculture, Forestry and Food of the Republic of Slovenia. The authors also acknowledge the vital contributions made by Klemen Kaučič, the head of the experimental field 'Center' owned by Perutnina Ptuj d.d.

\section{References}

Álvaro-Fuentes, J., Arrúe, J.L., Gracia, R. \& López, M.V. (2008). Tillage and cropping intensification effects on soil aggregation: Temporal dynamics and controlling factors under semiarid conditions. Geoderma, 145, 3-4, 390-396. ISSN : 0016-7061

Cookson, W.R., Murphya, D.V. \& Roperb, M.M. (2008). Characterizing the relationships between soil organic matter components and microbial function and composition along a tillage disturbance gradient. Soil Biology \& Biochemistry. 40, 763-777. ISSN: 0038-0717

Ellert, B.H. \& Janzen, H.H. (1999). Short-term influence of tillage no $\mathrm{CO}_{2}$ fluxes from a semi-arid soil on the Canadian Prairies. Soil and Tillage Research. 50, 21-32, ISSN: 0167-1987

Etana, A., Håkansson, I. Zagal, E. \&. Bucas, S. (1999). Effects of tillage depth on organic carbon content and physical properties in five Swedish soils Original Research Article, Soil and Tillage Research, 52, 3-4, 129-139. ISSN: 01671987

Gill, W.R. \& Vanden Berg, G.E. (1968). Soil Dynamics in Tillage and Traction, Agricultural Handbook No. 316. Agricultural Research Service, U.S. Department of Agriculture, Washington D. C., USA

Gregorich, E.G., Rochette, P., VandenBygaart, A.J. \& Angers, D.A. (2005). Greenhouse gas contributions of agricultural soils and potential mitigation practices in Eastern Canada, Soil and Tillage Research, 83/1, 53-72, ISSN: 0167-1987

Hao, X., Ball, B.C., Culley, J.L.B., Carter, M.R. \& Parkin, G.W. (2008). Soil density and porosity. In: Culley, J.L.B. \& Gregorich, E.G. (Eds.), Soil Sampling and Methods of Analysis. Taylor \& Francis Group. ISBN-13: 978-0-8493-3586-0, Boca Raton, FL 33487-2742, FL, USA

Jejčič, V., \& Poje, T. (1996). Determination of specific resistance of soil using the horizontal penetrometry method. 24. međunarodno savjetovanje iz područja mehanizacije poljoprovrede, Opatija 06. - 09. veljače 1996. Aktualni zadaci mehanizacije poljoprivrede : zbornik radova. Zagreb: Zavod za mehanizaciju poljoprivrede: Agronomski fakultet Sveučilišta u Zagrebu, 103-107. ISBN: 953-6135-14-0, Zagreb, Croatia 
Johnson, C.E. \& Bailey, A.C. (2002). Soil compaction. In: Upadhyaya, S.K., Chancellor, W.J., Perumpral, V. J., Schafer, R. L., Gill, R. W. \& Vendenberg, G. E. (Eds.) Advance in Soil Dynamics, vol. 2. ASAE, St. Joseph, MI, 155178, ISSN 1081-5627

Jones, D. \& Kunze, M. (2004). Guide to Sampling Soil Compaction Using HandHeld Soil Penetrometers; Center for Environmental Management of Military Lands (CEMML), Colorado State University: Fort Collins, CO, USA, $10 \mathrm{p}$

Lal, R. \& Bruce, J.P. (1999). The potential of world cropland soils to sequester C and mitigate the greenhouse effect. Environmental Science \& Policy, 2, 177-185. ISSN: 1462-9011

Reicosky, D.C., Reeves, D.W., Prior, S.A., Runion, G.B., Rogers, H.H. \& Raper, R.L. (1999). Effects of residue management and controlled traffic on carbon dioxide and water loss. Soil and Tillage Research. 52, 153-165, ISSN: 01671987

Six, J., Elliott, E.T. \& Paustian, K. (2000). Soil macroaggregate turnover and microaggregate formation: a mechanism for $\mathrm{C}$ sequestration under no-tillage agriculture. Soil Biology \& Biochemistry. 32, 2099-2103. ISSN: 0038-0717

Stajnko, D., Lakota, M., Vučajnk, F. \& Bernik, R. (2009a). The effect of different tillage systems on fuel saving and reduction of $\mathrm{CO} 2$ emmission in production of silage corn in Eastern Slovenia. Pol. J. Environ. Stud., 2009, vol. 18, no. 4, 709-714, ISSN: 1230-1485

Stajnko, D., Vindis, P. \& Mursec, B. (2009b). Reduction of $\mathrm{CO}_{2}$ emissions in production of corn in Slovenia, Chapter 56 in DAAAM International Scientific Book 2009, pp. 573-586, B. Katalinic (Ed.), Published by DAAAM International, ISBN 978-3-901509-69-8, ISSN 1726-9687, Vienna, Austria, DOI: $10.2507 /$ daaam.scibook.2009.56

Stockfisch, N., Forstreuter, T. \& Ehlers, W. (1999). Ploughing effects on soil organic matter after twenty years of conservation tillage in Lower Saxony, Germany, Soil \& Tillage Research, 52, 91-101, ISSN: 0167-1987

Wang, Q., Yuhua, B., Gao, H., He, J., Chen, H., Chesney, R.C., Kuhn, N.J. \& Li, H. (2008). Soil chemical properties and microbial biomass after 16 years of no-tillage farming on the Loess Plateau, China. Geoderma. 144, 502-508, ISSN: ISSN: 00167061 